\title{
MMP2 Gene-735 C/T and MMP9 gene-1562 C/T Polymorphisms in JAK2V617F Positive Myeloproliferative Disorders
}

\author{
Sebnem Ozemri Sag ${ }^{1}$, Ozlem Gorukmez ${ }^{1}$, Mehmet Ture¹, Orhan Gorukmez², \\ Ali Topak ${ }^{1}$, Serdar Sahinturk ${ }^{1}$, Gokhan Ocakoglu ${ }^{3}$, Tuna Gulten ${ }^{1}$, Ridvan Ali ${ }^{4}$, \\ Tahsin Yakut ${ }^{1 *}$
}

\begin{abstract}
Background: Myeloproliferative disorders (MPDs) are clonal hematologic malignancies originating at the level of the pluripotent hematopoietic stem cell. Matrix metalloproteases (MMPs) are proteolytic enzymes that contribute to all stages of malignancy progression. Genetic variants in the MMPgenes may influence the biological function of these enzymes and change their role in carcinogenesis and progression. To our knowledge, this is the first investigation of associations between the $-735 \mathrm{C} / \mathrm{T}$ and $-1562 \mathrm{C} / \mathrm{T}$ polymorphisms in the MMP2 and MMP9 genes, respectively, and the risk of essential thrombocytosis (ET), and polycythemia vera (PV). Materials and Methods: The case-control study included JAK2V617F mutation positive $102 \mathrm{ET}$ and PV patients and 111 controls. Polymorphisms were determined by using polymerase chain reaction-restriction fragment length polymorphism (PCR-RFLP) and electrophoresis. Results: No statistically significant differences were detected between patient $(\mathrm{ET}+\mathrm{PV})$ and control groups regarding genotype distribution for MMP2 gene-735 $\mathrm{C} / \mathrm{T}$ and MMP9 gene $-1562 \mathrm{C} / \mathrm{T}$ polymorphisms and $\mathrm{C} / \mathrm{T}$ allele frequency $(\mathrm{p}>0.050)$. Statistically borderline significance was observed between PV and control groups regarding genotype distribution for the MMP9 gene -1562 C/T polymorphism $(\mathrm{p}=\mathbf{0 . 0 5 0}, \mathrm{OR}=\mathbf{2 . 2 6}, 95 \% \mathrm{Cl}=\mathbf{0 . 9 9 - 5 . 1 6 )}$. Conclusions: Consequently this study supported that $\mathrm{CC}$ genotype of MMP9 gene $-1562 \mathrm{C} / \mathrm{T}$ polymorphism may be related with PV even if with borderline significance.
\end{abstract}

Keywords: Matrix metalloproteases - polymorphism - myeloproliferative disorders

Asian Pac J Cancer Prev, 16 (2), 443-449

\section{Introduction}

Myeloproliferative disorders is a group of diseases which are characterized by excessive production of cell abnormally and a persistent and progressive increase of mature cells in peripheral blood circulation arising from genetic mutations of multipotential hematopoietic stem cells and progenitor cells in bone marrow (Dameshek, 1951). They are divided into two main groups according to existence of philadelphia $(\mathrm{Ph})$ translocation, as BCRABL fusion gene positive and negative. While chronic myeloid leukemia (CML) is available in BCR-ABL fusion gene positive group, Polycythemia vera (PV), essential thrombocytosis (ET) and idiopathic myelofibrosis (IMF) are the BCR-ABL fusion gene-negative myeloproliferative neoplasms (Kaushansky, 2006; Barbui et al., 2011; Soriano and Heaney, 2013). In 1951 Dameshek W defined the relationship between these three diseases and stated that their basic features were hypercellularity in bone marrow, tendency for bleeding and/or thrombosis and leukemic transformation risk even if at low risk (7-10\%)
(Kaushansky, 2006; Haferlach et al., 2008). In the literature annual incidence for PV and ET is 1-3/100 000 while it is less often for IMF (Haferlach et al., 2008; Payandeh et al., 2011). In 2005 showing a point mutation in Janus Kinase 2 gene (JAK2) with a high ratio in this disorder group, provided great benefit for accurate diagnosis (Scott, 2013; Soriano and Heaney, 2013). This mutation was comprehended to occur in $\mathrm{PV}$ in $96 \%$ ratio while $55 \%$ in ET and 65\% in IMF (Tefferi and Vainchenker, 2011).

Matrix metalloproteinases (MMPs) which have key role in regulation of extracellular matrix are assigned in various biological pathways. MMPs are a multigenic endopeptidase family degrading the extracellular matrix which are active in neutral pH (Matrisian, 1990; Ennis and Matrisian, 1994; Thorgeirsson et al., 1994; Hewitt and Dan, 1996). They play an important role in degradation of collagen proteins as a target tissue. As well as being substantial enzymes in basic steps like organogenesis and vascularization, they are important for immune system and cancer etiology (Xiaoping and Yu, 2003). MMPs takes part in regulation of cellular processes like differentiation,

${ }^{1}$ Department of Medical Genetics, ${ }^{3}$ Department of Biostatistics, ${ }^{4}$ Department of Internal Medicine, Division of Hematology, Faculty of Medicine, Uludag University, ${ }^{2}$ Department of Medical Genetics, Sevket Yllmaz Education and Research Hospital, Bursa, Turkey *For correspondence: tahyakut@gmail.com 
proliferation, angiogenesis and apoptosis (Egeblad and Werb, 2002; Wagenaar-Miller et al., 2004; Gentner et al., 2009). MMP2 gene exists in 16q13-21 region and has thirteen exons (Saeed et al., 2013). MMP9 gene exists in 20q11region. MMP2 (Gelatinase A) and MMP9 (Gelatinase B) targets collagen type 4 basically. Collagen type 4 is fundamentally available in basal membranes. Polymorphisms for MMP2 and MMP9 genes were studied in different populations and functional polymorphisms at promoter region were identified. The MMP9-1562 C/T polymorphism was shown to exert a functional effect on gene transcription. This single nucleotide polymorphism (SNP) at $-1562 \mathrm{bp}$ is due to a $\mathrm{C}$ to $\mathrm{T}$ substitution (-1562C$\rightarrow \mathrm{T}$ ), which results in the loss of binding of a nuclear protein to this region and an increase in transcriptional activity in macrophages. In these cells, the CC genotype leads to a low promoter activity whereas the CT and TT genotypes result in high transcriptional activity (Zhang et al., 1999). Human MMP2 gene exhibits sequence variations and several functional single nucleotide polymorphisms (SNPs) in the MMP2 promoter have been described (Price et al., 2000; Harendza et al., 2003; Yu et al., 2004). CT polymorphism located at nucleotide destroys an Sp1 binding element, with the T allele being associated with significantly diminished promoter activity. Over expression of MMP-2 has been identified in many tumors types (Sanii et al., 2012). MMP2 -735 CC genotype was associated with an increased MMP-2 expression ( $\mathrm{Yu}$ et al., 2004). We aimed to investigate the potential role of polymorphisms of MMP2 gene - $735 \mathrm{C} / \mathrm{T}$ and MMP9 gene $-1562 \mathrm{C} / \mathrm{T}$ in pathogenesis of ET and PV.

\section{Materials and Methods}

\section{Study patients}

In this case control study $46 \mathrm{PV}$ and 56 ET patients meeting the World Health Organization (WHO) criteria (Wadleigh and Tefferi, 2010) who applied to Uludag University Faculty of Medicine, Medical Genetics Department for JAK2V617F mutation analysis with the prediagnosis of myeloproliferative disease and whose mutations were positive and 111 controls without any myeloproliferative disease and cancer diagnosis were included between 2009 and 2013 years. Clinical and laboratory features for the patients with myeloproliferative disease diagnosis [leukocyte and thrombocyte counts, hemoglobin levels, existence of splenomegaly, vascular event history and comorbid diseases (dyslipidemia, diabetes mellitus, hypertension)] were noted. Vascular events were defined as arterial and venous thrombosis including the transient ischemic attack, ischemic stroke, acute myocardial infarction, peripheral arterial thrombosis, deep vein thrombosis and pulmonary embolism. Local ethics committee approval was obtained.

\section{Genotyping}

Peripheral blood samples of patient and control groups were taken into EDTA tubes, isolated by Dr. Zeydanlı (DZ) DNA isolation kits and preserved at $-20^{\circ} \mathrm{C}$. Polymerase Chain Reaction-Restriction Length Fragment Polymorphism (PCR-RFLP) process was applied to detect gene polymorphisms of MMP2 -735 C/T and MMP9-1562 C/T. F: 5'-ATAGGGTAAACCTCCCCACATT-3' and R: 5'-GGTAAAATGAGGCTGAGACCTG-3' primers were used to determine MMP2 $-735 \mathrm{C} / \mathrm{T}$ gene polymorphism and F: 5'-GCCTGGCACATAGTAGGCCC-3' and R: 5'-CTTCCTAGCCAGCCGGCATC-3' primers were used to detect MMP9 -1562 C/T gene polymorphism PCR conditions were as follows: after the first denaturation for $5 \mathrm{~min}$ at $94^{\circ} \mathrm{C}$, denaturation continued for $1 \mathrm{~min}$ at $94^{\circ} \mathrm{C}$, which continued with 35 cycles of annealing for $1 \mathrm{~min}$ at $58^{\circ} \mathrm{C}$, and extension for $1 \mathrm{~min}$ at $72^{\circ} \mathrm{C}$, which ended with final extension for $10 \mathrm{~min}$ at $72^{\circ} \mathrm{C}$. The amplified PCR products for MMP2-735 C/T and MMP9 $-1562 \mathrm{C} / \mathrm{T}$ the polymorphisms were 300 base pairs (bp) and 435 bp, respectively. The HinfI, and SphI restriction enzymes (New England Biolabs, USA) were used to distinguish the MMP2 -735 C/T and MMP9 $-1562 \mathrm{C} / \mathrm{T}$, respectively. All PCR products were digested overnight at $37^{\circ} \mathrm{C}$ and analyzed on $4 \%$ agarose gels. The MMP $2-735 \mathrm{C} / \mathrm{T}$ allele generated fragments of 254bp and 46bp; the MMP9 $-1562 \mathrm{C} / \mathrm{T}$ allele generated fragments of $247 \mathrm{bp}$ and $188 \mathrm{bp}$ (Pereza et al., 2012).

\section{Statistical analyses}

Variables were represented as median(minimummaximum) or frequancy with related percentage values. Between group comparisons were performed by using Mann Whitney test, chi-square or Fisher's exact test. P value was set at 0.050 for statistical significance. Statistical analysis were performed by using SPSSv.20 for statistical software.

\section{Results}

Ages of the myeloproliferative patients' group (ET+ PV) were between 20 and 85 and median age was $58.5 ; 53$ $(52 \%)$ of them were female while $49(48 \%)$ of them were male. In control group who had no neoplasm history, ages distributed between 47 and 79 and median age was 55; 54 $(48.60 \%)$ of them were female while $57(51.40 \%)$ were male. Between patient and control groups, no differences were available in terms of age $(p=0.054)$ and gender $(\mathrm{p}=0.629)$. Clinical features of ET and PV patients were presented in Table 1.

Genotype distribution and allele frequencies of MMP2 -735 C/T and MMP9 -1562 C/T polymorphisms were presented in table 2 comperatively for ET, PV and control groups. Genotype distribution and allele frequencies of MMP2 -735 C/T and MMP9 -1562 C/T polymorphisms were similar between patient and control groups ( $\mathrm{p}>0.050$ ). Allele frequencies of MMP2 -735 C/T polymorphism $\mathrm{C}$ and $\mathrm{T}$ of patient and control groups were $84.38 \%$ and $15.63 \%$ and $84.80 \%$ and $15.20 \%$ respectively. As for allele frequencies of $\mathrm{C}$ and $\mathrm{T}$ of MMP9 -1562 $\mathrm{C} / \mathrm{T}$ polymorphism of patient and control groups, the results were $84.80 \%$ and $15.20 \%$ and $82.27 \%$ and $17.73 \%$ respectively.

No significant differences were available in genotype distribution and allele frequencies of MMP2 -735 C/T polymorphism between ET and PV patients ( $\mathrm{p}>0.050)$. Statistically significant differences were found in genotype 
Table 1. Clinical Features of ET and PV Patients

\begin{tabular}{lccr}
\hline Clinical features & ET $(\mathrm{n}=56)$ & PV $(\mathrm{n}=46)$ & $\mathrm{p}$ value \\
\hline Age $($ years $)$ & $62.50(20-85)^{*}$ & $57.50(28-84)^{*}$ & 0.549 \\
Gender $($ female/male $)$ & $31 / 25$ & $22 / 24$ & 0.577 \\
$\mathrm{Hb}(\mathrm{g} / \mathrm{dL})$ & $13.80(10-16.70)^{*}$ & $18(10.60-21.30)^{*}$ & $<0.001$ \\
$\mathrm{Plt}\left(\mathrm{x} 10^{9} / \mathrm{L}\right)$ & $784(288-1560)^{*}$ & $486.50(173-1221)^{*}$ & $<0.001$ \\
$\mathrm{WBC} * * *\left(\times 10^{9} / \mathrm{L}\right)$ & $11.80(5-32.10)^{*}$ & $13.15(5.20-34.90)^{*}$ & 0.404 \\
$\mathrm{WBC}^{* * *}\left(>10 \times 10^{9} / \mathrm{L}\right.$ & $36(66.70)^{* *}$ & $29(65.90)^{* *}$ & 1,000 \\
$\mathrm{WBC}^{* * *}\left(\leq 10 \times 10^{9} / \mathrm{L}\right)$ & $18(33.30)^{* *}$ & $15(34.10)^{* *}$ & \\
Splenomegaly & $15(27.30)^{* *}$ & $13(29.50)^{* *}$ & 0.980 \\
\hline
\end{tabular}

ET, Essential Thrombocytosis; PV, Polycythemia Vera; Hb, Hemoglobin; Plt, Platelets; WBC, White Blood Cells; *Median (minimum-maximum); $* * \mathrm{n}(\%) ; * * \mathrm{WBC}$ was calculated for 98 patients

Table 2. Comperative Results of Genotype Distribution and Allele Frequency of MMP2 -735 C/T and MMP9 -1562 C/T Gene Polymorphism in Patient Group (ET+PV), ET Patients, PV Patients and Control Groups

\begin{tabular}{|c|c|c|c|c|c|c|c|c|c|c|c|c|c|c|}
\hline & $\begin{array}{c}\text { ET } \\
(n=52)\end{array}$ & $\begin{array}{c}P V \\
(n=44)\end{array}$ & $\begin{array}{c}\mathrm{p} \\
\text { value }\end{array}$ & $\begin{array}{c}\text { OR } \\
(95 \% \mathrm{Cl})\end{array}$ & $\begin{array}{c}\mathrm{ET}+\mathrm{PV} \\
(\mathrm{n}=96)\end{array}$ & $\begin{array}{c}C G \\
(n=102)\end{array}$ & $\begin{array}{c}\mathrm{p} \\
\text { value }\end{array}$ & $\begin{array}{c}\text { ET } \\
(n=52)\end{array}$ & $\begin{array}{c}C G \\
(n=102)\end{array}$ & $\begin{array}{c}\mathrm{p} \\
\text { value }\end{array}$ & $\begin{array}{c}\text { PV } \\
(n=44)\end{array}$ & $\begin{array}{c}C G \\
(n=102)\end{array}$ & $\begin{array}{c}\mathrm{p} \\
\text { value }\end{array}$ & $\begin{array}{c}\text { OR } \\
(95 \% \mathrm{Cl})\end{array}$ \\
\hline \multicolumn{15}{|c|}{ MMP2- 735C/T } \\
\hline $\mathrm{CC}$ & $\begin{array}{c}39 \\
(75)^{*}\end{array}$ & $\begin{array}{c}29 \\
(65.90)^{*}\end{array}$ & 0.453 & - & $\begin{array}{c}68 \\
(70.80)^{*}\end{array}$ & $\begin{array}{c}73 \\
(71.60)^{*}\end{array}$ & 1,000 & $\begin{array}{c}39 \\
(75)^{*}\end{array}$ & $\begin{array}{c}73 \\
(71.60)^{*}\end{array}$ & 0.794 & $\begin{array}{c}29 \\
(65.90)^{*}\end{array}$ & $\begin{array}{c}73 \\
(71.60)^{*}\end{array}$ & 0.626 & - \\
\hline $\mathrm{CT}$ & $\begin{array}{c}12 \\
(23.10)^{*}\end{array}$ & $\begin{array}{c}14 \\
(31.80)^{*}\end{array}$ & 0.466 & - & $\begin{array}{c}26 \\
(27.10)^{*}\end{array}$ & $\begin{array}{c}27 \\
(26.50)^{*}\end{array}$ & 0.922 & $\begin{array}{c}12 \\
(23.10)^{*}\end{array}$ & $\begin{array}{c}27 \\
(26.50)^{*}\end{array}$ & 0.793 & $\begin{array}{c}14 \\
(31.80)^{*}\end{array}$ & $\begin{array}{c}27 \\
(26.50)^{*}\end{array}$ & 0.646 & - \\
\hline TT & $\begin{array}{c}1 \\
(1.90)^{*}\end{array}$ & $\begin{array}{c}1 \\
(2.3)^{*}\end{array}$ & 1,000 & - & $\begin{array}{c}2 \\
(2.10)^{*}\end{array}$ & $\begin{array}{c}2 \\
(2)^{*}\end{array}$ & 1,000 & $\begin{array}{c}1 \\
(1.90)^{*}\end{array}$ & $\begin{array}{c}2 \\
(2)^{*}\end{array}$ & 1,000 & $\begin{array}{c}1 \\
(2.30)^{*}\end{array}$ & $\begin{array}{c}2 \\
(2)^{*}\end{array}$ & 1,000 & - \\
\hline $\mathrm{C}$ & $\begin{array}{c}90 \\
(86.54)^{*}\end{array}$ & $\begin{array}{c}72 \\
(81.82)^{*}\end{array}$ & & & $\begin{array}{c}162 \\
(84.38)^{*}\end{array}$ & $\begin{array}{c}173 \\
(84.80)^{*}\end{array}$ & & $\begin{array}{c}90 \\
(86.54)^{*}\end{array}$ & $\begin{array}{c}173 \\
(84.80)^{*}\end{array}$ & & $\begin{array}{c}72 \\
(81.82)^{*}\end{array}$ & $\begin{array}{c}173 \\
(84.80)^{*}\end{array}$ & - & \\
\hline \multirow[t]{2}{*}{$\mathrm{T}$} & $\begin{array}{c}14 \\
(13.46)^{*}\end{array}$ & $\begin{array}{c}16 \\
(18.18)^{*}\end{array}$ & 0.369 & - & $\begin{array}{c}30 \\
(15.63)^{*}\end{array}$ & $\begin{array}{c}31 \\
(15.20)^{*}\end{array}$ & 1,000 & $\begin{array}{c}14 \\
(13.46)^{*}\end{array}$ & $\begin{array}{c}31 \\
(15.20)^{*}\end{array}$ & 0.684 & $\begin{array}{c}16 \\
(18.18)^{*}\end{array}$ & $\begin{array}{c}31 \\
(15.20)^{*}\end{array}$ & 0.643 & - \\
\hline & $\begin{array}{c}\text { ET } \\
(n=56)\end{array}$ & $\begin{array}{c}\text { PV } \\
(n=46)\end{array}$ & $\begin{array}{c}\mathrm{p} \\
\text { value }\end{array}$ & $\begin{array}{c}\text { OR } \\
(95 \% \mathrm{Cl})\end{array}$ & $\begin{array}{c}\mathrm{ET}+\mathrm{PV} \\
(\mathrm{n}=102)\end{array}$ & $\begin{array}{c}C G \\
(n=110)\end{array}$ & $\begin{array}{c}\mathrm{p} \\
\text { value }\end{array}$ & $\begin{array}{c}\text { ET } \\
(n=56)\end{array}$ & $\begin{array}{c}\text { CG } \\
(n=110)\end{array}$ & $\begin{array}{c}\mathrm{p} \\
\text { value }\end{array}$ & $\begin{array}{c}\text { PV } \\
(n=46)\end{array}$ & $\begin{array}{c}C G \\
(n=110)\end{array}$ & $\begin{array}{c}\mathrm{p} \\
\text { value }\end{array}$ & $\begin{array}{c}\text { OR } \\
(95 \% \mathrm{Cl})\end{array}$ \\
\hline \multicolumn{15}{|c|}{ MMP9- 1562C/T** } \\
\hline $\mathrm{CC}$ & $\begin{array}{c}34 \\
(60.70)^{*}\end{array}$ & $\begin{array}{c}37 \\
(80.40)^{*}\end{array}$ & & & $\begin{array}{c}71 \\
(69.60)^{*}\end{array}$ & $\begin{array}{c}71 \\
(64.50)^{*}\end{array}$ & & $\begin{array}{c}34 \\
(60.70)^{*}\end{array}$ & $\begin{array}{c}71 \\
(64.50)^{*}\end{array}$ & & $\begin{array}{c}37 \\
(80.40)^{*}\end{array}$ & $\begin{array}{c}71 \\
(64.50)^{*}\end{array}$ & 0.050 & \\
\hline $\mathrm{CT}$ & $\begin{array}{c}22 \\
(39.30)^{*}\end{array}$ & $\begin{array}{c}9 \\
(19.60)^{*}\end{array}$ & 0.031 & $\begin{array}{c}2.66 \\
(1.08-6.58)\end{array}$ & $\begin{array}{c}31 \\
(30.40)^{*}\end{array}$ & $\begin{array}{c}39 \\
(35.50) *\end{array}$ & 0.434 & $\begin{array}{c}22 \\
(39.30)^{*}\end{array}$ & $\begin{array}{c}39 \\
(35.50)^{*}\end{array}$ & 0.754 & $\begin{array}{c}9 \\
(19.60)^{*}\end{array}$ & $\begin{array}{c}39 \\
(35.50)^{*}\end{array}$ & & $\begin{array}{c}2.26 \\
(0.99-5.16)\end{array}$ \\
\hline $\mathrm{C}$ & $\begin{array}{c}90 \\
(80.36)^{*}\end{array}$ & $\begin{array}{c}83 \\
(90.22)^{*}\end{array}$ & 0.051 & - & $\begin{array}{c}173 \\
(84.80)^{*}\end{array}$ & $\begin{array}{c}181 \\
(82.27)^{*}\end{array}$ & & $\begin{array}{c}90 \\
(80.36)^{*}\end{array}$ & $\begin{array}{c}181 \\
(82.27)^{*}\end{array}$ & & $\begin{array}{c}83 \\
(90.22)^{*}\end{array}$ & $\begin{array}{c}181 \\
(82.27)^{*}\end{array}$ & 0.109 & - \\
\hline $\mathrm{T}$ & $\begin{array}{c}22 \\
(19.64)^{*}\end{array}$ & $\begin{array}{c}9 \\
(9.78)^{*}\end{array}$ & & & $\begin{array}{c}31 \\
(15.20)^{*}\end{array}$ & $\begin{array}{c}39 \\
(17.73)^{*}\end{array}$ & 0.483 & $\begin{array}{c}22 \\
(19.64)^{*}\end{array}$ & $\begin{array}{c}39 \\
(17.73)^{*}\end{array}$ & 0.782 & $\begin{array}{c}9 \\
(9.78)^{*}\end{array}$ & $\begin{array}{c}39 \\
(17.73)^{*}\end{array}$ & & \\
\hline
\end{tabular}

ET: Essential Thrombocytosis, PV: Polycythemia Vera, CG: Control Group, Cl=confidence interval; OR=odds ratio; *n (\%); **TT genotype was not observed for MMP9- 1562C/T polymorphism

Table 3. Clinical Features of Patients Group with and Without Vascular Events

\begin{tabular}{llll}
\hline & VEP $(\mathrm{n}=31)$ & VEN $(\mathrm{n}=70)$ & $\mathrm{p}$ value \\
\hline Age $($ years $)$ & $59(33-85)^{* *}$ & $58(20-84)^{* *}$ & 0.393 \\
Age $<60$ & $16(51.60)^{*}$ & $36(51.40)^{*}$ & 1,000 \\
Age $\geq 60$ & $15(48.40)^{*}$ & $34(48.60)^{*}$ & \\
WBC $* * *$ & 12.10 & 12.70 & 0.771 \\
$\left(\mathrm{x} 10^{9} / \mathrm{L}\right)$ & $(6.30-26.60)^{* *}$ & $(5-34.90)^{* *}$ & \\
WBC $* * *$ & $19(61.30)^{*}$ & $46(68.70)^{*}$ & 0.626 \\
$\left(>10 \times 10^{9} / \mathrm{L}\right)$ & & & \\
WBC & & & \\
$\left(\leq 10 \times 10^{9} / \mathrm{L}\right)$ & $12(38.70)^{*}$ & $21(31.30)^{*}$ & \\
$\mathrm{Hb}(\mathrm{g} / \mathrm{dL})$ & 15.20 & & \\
& $(10-19.60)^{* *}$ & $(10.45$ & 0.417 \\
$\mathrm{Plt}\left(\mathrm{x} 10^{9} / \mathrm{L}\right)$ & 770 & 676.50 & 0.437 \\
& $(185-1254)^{* *}$ & $(173-1560)^{* *}$ & \\
DM & $2(6.50)^{*}$ & $5(7.10)^{*}$ & 1,000 \\
$\mathrm{DL}$ & $6(19.40)^{*}$ & $3(4.30)^{*}$ & 0.023 \\
$\mathrm{HT}$ & $11(35.50)^{*}$ & $19(27.10)^{*}$ & 0.542 \\
Chronic disease & $15(48.40)^{*}$ & $22(31.40)^{*}$ & 0.159 \\
\hline
\end{tabular}

VEP: Vascular Event Positive, VEN: Vascular Event Negative DM: Diabetes Mellitus, DL: Dyslipidemia HT: Hypertension, Chronic disease $(\mathrm{DM}+\mathrm{DL}+\mathrm{HT}) \mathrm{Hb}$ : Hemoglobin, Plt: Platelets, WBC: White Blood Cells; *n (\%); **Median (minimum-maximum); ***WBC was calculated in 67 patients for VEN group distribution of MMP9 - $1562 \mathrm{C} / \mathrm{T}$ polymorphism between ET and PV patients $(\mathrm{p}=0.031, \mathrm{OR}=2.66,95 \% \mathrm{Cl}=1.08$ 6.58) while borderline significant difference was available in terms of $\mathrm{C} / \mathrm{T}$ allele frequencies $(\mathrm{p}=0.051)$. $\mathrm{CC}$ genotype was found to be significantly higher in PV patients compared to ET group $(\mathrm{p}=0.031$, OR=2.66, 95\% $\mathrm{Cl}=1.08-6.58$ ).

Genotype distribution and allele frequencies of MMP9 $-1562 \mathrm{C} / \mathrm{T}$ polymorphism were similar between ET and control groups $(\mathrm{p}>0.050)$. While a borderline significant difference was observed between PV and control patients in terms of genotype distribution of MMP9 $-1562 \mathrm{C} / \mathrm{T}$ polymorphism $(\mathrm{p}=0.050, \mathrm{OR}=2.26,95 \% \mathrm{Cl}=0.99-5.16)$, $\mathrm{C} / \mathrm{T}$ allele frequencies were similar $(\mathrm{p}>0.050)$. CC genotype was found to be borderline significant in $\mathrm{PV}$ patients compared to control group $(\mathrm{p}=0.050, \mathrm{OR}=2.26$, $95 \% \mathrm{Cl}=0.99-5.16)$.

Clinical and laboratory features of myeloproliferative patients' group with or without vascular event history were presented in Table 3. Dyslipidemia was found significantly higher in ET and PV patients with vascular event history $(p=0.023)$. Genotype distribution and allele frequencies of MMP2 -735 C/T and MMP9 -1562 C/T polymorphisms 
Table 4. Comperative results of Genotype Distribution and Allele Frequency of MMP2 -735 C/T and MMP9 -1562 C/T Gene Polymorphism in Patients Group with and without Vascular Events and with and without Hypertension

\begin{tabular}{|c|c|c|c|c|c|c|c|}
\hline & $\operatorname{VEP}(n=28)$ & VEN $(n=68)$ & $\begin{array}{c}\mathrm{p} \\
\text { value }\end{array}$ & $\operatorname{HTP}(n=28)$ & HTN $(n=68)$ & $\begin{array}{c}\mathrm{p} \\
\text { value }\end{array}$ & $\begin{array}{c}\text { OR } \\
(95 \% \mathrm{Cl})\end{array}$ \\
\hline \multicolumn{8}{|c|}{ MMP2 - $735 \mathrm{C} / \mathrm{T}$} \\
\hline $\mathrm{CC}$ & $19(67.90) *$ & $49(72.10) *$ & 0.869 & $15(53.60) *$ & $53(77.90) *$ & 0.032 & $3.06(1.20-7.83)$ \\
\hline CT & $8(28.60) *$ & $18(26.50) *$ & 1,000 & $12(42.90) *$ & $14(20.60) *$ & 0.048 & $2.89(1.11-7.49)$ \\
\hline TT & $1(3.60) *$ & $1(1.50) *$ & 0.500 & $1(3.60) *$ & $1(1.50) *$ & 0.500 & - \\
\hline $\mathrm{C}$ & $46(82.14) *$ & $116(85.29) *$ & 0.743 & $42(75) *$ & $120(88.24) *$ & 0.038 & $2.50(1.13-5.56)$ \\
\hline \multirow[t]{2}{*}{$\mathrm{T}$} & $10(17.86) *$ & $20(14.71) *$ & & $14(25) *$ & $16(11.76)^{*}$ & & \\
\hline & $\operatorname{VEP}(n=31)$ & $\operatorname{VEN}(n=70)$ & & $\operatorname{HTP}(n=30)$ & $\operatorname{HTN}(n=71)$ & & \\
\hline \multicolumn{8}{|c|}{ MMP9 - 1562 C/T** } \\
\hline $\mathrm{CC}$ & $18(58.10) *$ & $52(74.30) *$ & 0.163 & $19(63.30) *$ & $51(71.80) *$ & 0.542 & - \\
\hline $\mathrm{CT}$ & $13(41.90) *$ & $18(25.70) *$ & & $11(36.70) *$ & $20(28.20) *$ & & \\
\hline $\mathrm{C}$ & $49(79.03)^{*}$ & $122(87.14) *$ & 0.206 & $49(81.67)^{*}$ & $122(85.92) *$ & 0.444 & - \\
\hline $\mathrm{T}$ & $13(20.97)^{*}$ & $18(12.86) *$ & & $11(18.33)^{*}$ & $20(14.08) *$ & & \\
\hline
\end{tabular}

VEP:Vascular Event Positive, VEN:Vascular Event Negative , HTP:Hypertension Positive, HTN:Hypertension Negative, Cl=confidence interval; $\mathrm{OR}=$ odds ratio; *n (\%); **TT genotype was not observed for MMP9-1562C/T polymorphism

were similar between myeloproliferative patients' group with and without vascular event history (Table 4).

While genotype distribution and allele frequencies of MMP9 - $1562 \mathrm{C} / \mathrm{T}$ polymorphisms were similar between myeloproliferative patients having hypertension and not $(\mathrm{p}>0.050)$, genotype distribution $(\mathrm{p}<0.050)$ and allele frequencies of MMP2 $-735 \mathrm{C} / \mathrm{T}(\mathrm{p}=0.038, \mathrm{OR}=2.50$, $95 \% \mathrm{Cl}=1.13-5.56$ ) differed significantly between patients with and without hypertension. CC genotype $(\mathrm{p}=0.032$, $\mathrm{OR}=3.06,95 \% \mathrm{Cl}=1.20-7.83)$ and $\mathrm{C}$ allele frequency were significantly higher in patients without hypertension while CT genotype $(\mathrm{p}=0.048, \mathrm{OR}=2.89,95 \% \mathrm{Cl}=1.11-7.49)$ and $\mathrm{T}$ allele frequency were significantly higher in patients with hypertension (Table 4).

\section{Discussion}

Genotype distribution and allele frequencies of MMP2 -735 C/T and MMP9 -1562 C/T polymorphisms were similar between patient groups of ET and PV and control group. CC genotype of MMP9 -1562 C/T polymorphism was found to be borderline significant in PV patients compared to control group

MMPs take part in physiological extracellular matrix modelling for tissue regeneration, wound healing and embryo development as well as playing role in pathological states such as arthritis, atherosclerosis and autoimmune skin diseases. Besides there are some evidence that MMPs are essential in various steps of cancer development by regulating cell proliferation, apoptosis, angiogenesis and immunosurveillance (Egeblad and Werb, 2002; Decock et al., 2008). MMP2 degrades some bioactive molecules like gelatin, type 4 collagen, growth factor receptor, and growth factor binding proteins. It is overexpressed in many cancers like gastric, lung, prostate, ovary, esophagus, oral and bladder cancers (Yu et al., 2004; Wu et al., 2007). While MMP9 expressed in low levels in physiological conditions, it increases dramatically in various neoplasms like oral, esophagus, breast, renal, colorectal cancers and melanomas (Wang et al., 2005; Awakura et al., 2006; Vairaktaris et al., 2008).

Normal physiological process of hematopoiesis and proliferation, differentiation and migration of hematopoietic stem cells are regulated by complex relations between bone marrow microenvironment, cytokines and extracellular matrix molecules. In recent studies it has been shown that MMPs had important role in development of hematologic malignancies. Most of the studies focus on role of gelatinases in leukemia (Yu and Han, 2006). In normal bone marrow, while MMP2 and 9 are available in myeloid cells and megakaryocytes, MMP2 has been shown erythroblasts too (Ogawa et al., 2000). In long-term cultures of bone marrows of normal donors, decresed expression of proMMP 9 and increased expression of proMMP2 was indicated (Marquez-Curtis et al., 2001). MMPs are related with thrombopoiesis. Stromal cell-derived factor 1(sdf-1) regulates the transendothelial migration of megakaryocytes and there are studies reporting that they enhance platelet production by stimulating MMP9 expression in mature megakaryocytes (Lane et al., 2000; Majka et al., 2000).

Buggins et al. (2011) remarked that serum MMP9 levels may be useful in predicting prognosis and clinical outcomes of CLL patients in early periods. Travaglino et al. (2008) reported abnormal expression of MMP2 and MMP9 in myelodysplastic syndrome (MDS) and acute myeloid leukemia (AML) patients. Kuittinen et al. (2001) found prominent difference in expression of MMP2 and MMP9 of pediatric and adult acute lymphoblastic leukemia (ALL) patients. While blast cells were dyed positively for MMP2 in $65 \%$ of adult ALL group, this rate was $25 \%$ for MMP9. Positivity ratio in pediatric group for both antibodies was $12.7 \%$. MMP2 expression was found to be related with extramedullary disease pattern in adult ALL patients. In the same study survival rates of adult ALL cases with MMP 9 positive blasts were found to be low, whereas there was not any relationship between survival and MMP expression in pediatric ALL patients. 
Yu et al. (2004) associated CC genotype of MMP2 gene $-735 \mathrm{C} / \mathrm{T}$ polymorphism with increased MMP2 expression, increased esophagus cancer risk and metastasis risk for the first time. Yari et al. (2014) indicated that the C allele of MMP-2 C-735T polymorphism is associated with increased risk of breast cancer. Srivastava et al. (2013) indicated a significant risk for bladder cancers when TT genotype is combined with heterozygous CT genotype for MMP2 gene - $735 \mathrm{C} / \mathrm{T}$ polymorphism. Zhou et al. (2005) found that CC genotype of MMP2 gene $-735 \mathrm{C} / \mathrm{T}$ polymorphism is associated with lung cancer development. Guo et al. (2012) found that MMP2 gene$735 \mathrm{C} / \mathrm{T}$ polymorphism influence susceptibility to lung cancer in Asians. Park et al. (2011) did not find significant differences between colorectal cancer patients and control group for MMP2 gene-735 C/T polymorphism. Hu et al. (2013) could not show a significant association between lung cancer development and MMP2 gene-735 C/T polymorphism in a meta-analysis comprising 3 studies. In our study, the results were similar between patient group (ET+PV) and control group regarding genotype distribution and allele frequency of MMP2 gene- $735 \mathrm{C} / \mathrm{T}$ polymorphism.

$\mathrm{Li}$ et al. (2013) reported that increased expression of MMP-9 was associated with poor prognosis in ovarian cancer patients. Zhang et al. (1999) indicated that a C-T substitution prevented nuclear proteins to bind on promoter region of MMP9 gene thus leading to increased transcriptional activity of macrophages. Cancer and MMP9 $-1562 \mathrm{C} / \mathrm{T}$ polymorphism relationship was investigated most frequently and different relationships in different cancers were observed for both alleles. Sfar et al. (2007) remarked that $C$ allele was related to decreased prostate cancer risk while $\mathrm{T}$ allele increased prostate cancer risk 3 times. Rollin et al. (2007) showed that C allele was associated with increased risk for squamous cell carcinoma of the lung. Sugimoto et al. (2006) associated $\mathrm{C}$ allele with endometrial carcinoma risk while Woo et al. (2007) correlated it with colorectal cancer risk. Yang et al. (2014) did not detect any relationship between MMP9 $-1562 \mathrm{C} / \mathrm{T}$ polymorphism and risk of gastric cancer in a meta-analysis comprising 4 studies. Langers et al. (2008) did not detect any relationship between MMP9 - $1562 \mathrm{C} / \mathrm{T}$ polymorphism and colorectal cancer while Wang et al. (2005) did not correlate it with non-small cell lung cancer and $\mathrm{Li}$ et al. (2006) did not find any relationship with ovary cancer. In our study genotype distribution and allele frequencies of MMP9 $-1562 \mathrm{C} / \mathrm{T}$ polymorphism were similar between patient $(\mathrm{ET}+\mathrm{PV})$ and control groups.

In our study we observed a borderline significant relationship between CC genotype of MMP9 gene $-1562 \mathrm{C} / \mathrm{T}$ polymorphism and PV development risk, that this results are partially compatible with the studies mentioned above may indicate that $\mathrm{CC}$ genotype would have a relationship with myeloproliferative diseases. Later on, studies about MMP2 gene - $735 \mathrm{C} / \mathrm{T}$ and MMP9 gene-1562 C/T polymorphisms on larger patient groups would yield more accurate results for myeloproliferative diseases and effect of MMP9 $-1562 \mathrm{C} / \mathrm{T}$ polymorphism on erythroblasts. The different results regarding MMP2 gene $-735 \mathrm{C} / \mathrm{T}$ and MMP9 $-1562 \mathrm{C} / \mathrm{T}$ polymorphisms and cancer development risks may be derived from ethnical heterogeneity, study design differences, features of the patients included, gene- gene and gene-environment interactions. Besides, these results indicate that different genotypes of MMP2 $-735 \mathrm{C} / \mathrm{T}$ and MMP9 $-1562 \mathrm{C} / \mathrm{T}$ polymorphisms may act differently in different tissues of various malignant diseases.

Thrombotic events for both arterial and venous system are seen in 30-50\% of PV and ET patients and accounts for 35-45\% of deaths (Gruppo Italiano Studio Policitemia, 1995; Besses et al., 1999; Marchioli et al., 2005). In our study, nearly one third of patients with ET and PV had vascular event history. There are some studies reporting age, previous vascular event history, hypertension, hyperlipidemia, presence of JAK2V617F mutation and leukocytosis to be risk factors for thrombosis in ET and PV patients. Mehtap et al. (2012) reported that older age and leukocytosis were risk factors for vascular events in ET and PV patients. In our study we did not detect any differences except dyslipidemia in clinical and laboratory features of patients with ET and PV having vascular event history or not. Coexisting dyslipidemia has been found to be a risk factor for vascular events in ET and PV patients in our study.

Zhang et al. (1999) reported that T allele of MMP9 gene $-1562 \mathrm{C} / \mathrm{T}$ polymorphism was associated with two times higher promoter activity and that the patients carrying $\mathrm{T}$ alelle had greater risk for severe cardiac atherosclerosis. Wang et al. (2001) detected higher frequency of $\mathrm{T}$ allele carriers in three-vessel disease patients. Malaponte et al. (2013) reported that CC genotype of MMP9 gene $-1562 \mathrm{C} / \mathrm{T}$ polymorphism to be related with deep vein thrombosis in cancer patients. Szczudlik and Borratynska, (2010) found no association between -1562 C/T MMP9 polymorphism and ischaemic stroke, subarachnoid haemorrhage or spontaneous intracerebral haemorrhage in the studied Polish population. Vasku et al. (2004) did not detect a relationship between MMP2 gene $-735 \mathrm{C} / \mathrm{T}$ polymorphism and three-vessel disease. That ET and PV patients with and without vascular event history had similar results with the control group regarding genotype distribution and allele frequencies of MMP2 $-735 \mathrm{C} / \mathrm{T}$ and MMP9 - 1562 C/T polymorphisms in our study, supports that these polymorphisms and thrombosis risk are not related to each other.

Palei et al. (2012) reported that T allele of MMP9 $-1562 \mathrm{C} / \mathrm{T}$ polymorphism was associated with gestational hypertension. Bayramoglu et al. (2013) did not observe a relationship between essential hypertension and 1562 polymorphism. Lacchini et al. (2012) found genotype distribution and allele frequencies of MMP2 gene -735 $\mathrm{C} / \mathrm{T}$ polymorphism to be similar between hypertensive individuals and healthy controls. In our study genotype distribution and allele frequencies of MMP9 -1562 C/T polymorphism was similar between ET and PV patients with and without hypertension, also $\mathrm{T}$ allele of MMP2 gene $-735 \mathrm{C} / \mathrm{T}$ polymorphism creates a tendecy towards hypertension in ET and PV patients.

In conclusion, this study revealed findings indicating that $\mathrm{CC}$ genotype of MMP9 gene $-1562 \mathrm{C} / \mathrm{T}$ polymorphism may be a risk factor for PV development while $\mathrm{T}$ allele 
Sebnem Ozemri Sag et al

of MMP2 gene $-735 \mathrm{C} / \mathrm{T}$ polymorphism may be a risk factor for hypertension in ET and PV patients. Future studies with larger patient groups will prove more accurate information for establishing a connection between these polymorphisms and myeloproliferative disease and hypertension risk.

\section{References}

Awakura Y, Ito N, Nakamura E, et al (2006). Matrix metalloproteinase-9 polymorphisms and renal cell carcinoma in a Japanese population. Cancer Lett, 241, 59-63.

Barbui T, Barosi G, Birgegard G, et al (2011). Philadelphianegative classical myeloproliferative neoplasms: critical concepts and management recommendations from European LeukemiaNet. J Clin Oncol, 29, 761-70.

Bayramoglu A, Urhan Kucuk M, Guler HI, et al (2013). Is there any genetic predisposition of MMP-9 gene C1562T and MTHFR gene C677T polymorphisms with essential hypertension? Cytotechnology, Nov 21. [Epub ahead of print]

Besses C, Cervantes F, Pereira A, et al (1999). Major vascular complications in essential thrombocythemia: a study of the predictive factors in a series of 148 patients. Leukemia, 13, 150-4.

Buggins AG, Levi A, Gohil S, et al (2011). Evidence for a macromolecular complex in poor prognosis CLL that contains CD38, CD49d, CD44 and MMP-9. Br J Haematol, 154, 216-22.

Dameshek W (1951). Some speculations on the myeloproliferative syndromes. Blood, 6, 372-5.

Decock J, Paridaens R, Ye S (2008). Genetic polymorphisms of matrix metalloproteinases in lung, breast and colorectal cancer. Clin Genet, 73, 197-211.

Egeblad M, Werb Z (2002). New functions for the matrix metalloproteinases in cancer progression. Nat Rev Cancer, 2, 161-74.

Ennis BW, Matrisian LM (1994). Matrix degrading metalloproteinases. J Neuro Oncol, 18, 105-9.

Gentner B, Wein A, Croner RS, et al (2009). Differences in the gene expression profile of matrix metalloproteinases (MMPs) and their inhibitors (TIMPs) in primary colorectal tumors and their synchronous liver metastases. Anticancer Res, 29, 67-74.

Gruppo Italiano Studio Policitemia (1995). Polycythemia vera: the natural history of 1213 patients followed for 20 years. Ann Intern Med, 123, 656-64.

Guo XT, Wang JF, Zhang LY, Xu GQ (2012). Quantitative assessment of the effects of MMP-2 polymorphisms on lung carcinoma risk. Asian Pac J Cancer Prev, 13, 2853-6.

Haferlach T, Bacher U, Kern W, Schnittger S, Haferlach C (2008). The diagnosis of BCR/ABL-negative chronic myeloproliferative diseases (CMPD): a comprehensive approach based on morphology, cytogenetics, and molecular markers. Ann Hematol, 87, 1-10.

Harendza S, Lovett DH, Panzer U, et al (2003). Linked common polymorphisms in the gelatinase a promoter are associated with diminished transcriptional response to estrogen and genetic fitness. J Biol Chem, 278, 20490-9.

Hewitt R, Dan K (1996). Stromal cell expression of components of matrixdegrading protease systems in human cancer. Enzyme Protein, 49, 163-73.

$\mathrm{Hu}$ C, Wang J, Xu Y, et al (2013). Current evidence on the relationship between five polymorphisms in the matrix metalloproteinases (MMP) gene and lung cancer risk: a meta-analysis. Gene, 517, 65-71.

Kaushansky K (2006). Hematopoietic growth factors, signaling and the chronic myeloproliferative disorders. Cytokine Growth Factor Rev, 17, 423-30.

Kuittinen O, Savolainen ER, Koistinen P, Möttönen M, Turpeenniemi-Hujanen T (2001). MMP-2 and MMP-9 expression in adult and childhood acute lymphatic leukemia (ALL). Leuk Res, 25, 125-31.

Lacchini R, Jacob-Ferreira AL, Luizon MR, et al (2012). Common matrix metalloproteinase 2 gene haplotypes may modulate left ventricular remodelling in hypertensive patients. J Hum Hypertens, 26, 171-7.

Lane WJ, Dias S, Hattori K, et al (2000). Stromal-derived factor 1-induced megakaryocyte migration and platelet production is dependent on matrix metalloproteinases. Blood, 96, 4152-9.

Langers AM, Sier CF, Hawinkels LJ, et al (2008). MMP-2 geno-phenotype is prognostic for colorectal cancer survival, whereas MMP-9 is not. Br J Cancer, 98, 820-3.

Li LN, Zhou X, Gu Y, Yan J (2013). Prognostic value of MMP9 in ovarian cancer: a meta-analysis. Asian Pac J Cancer Prev, 14, 4107-13.

Li Y, Jin X, Kang S, et al (2006). Polymorphisms in the promoter regions of the matrix metalloproteinases- $1,-3,-7$, and -9 and the risk of epithelial ovarian cancer in China. Gynecol Oncol, 101, 92-6.

Majka M, Janowska-Wieczorek A, Ratajczak J, et al (2000). Stromal-derived factor 1 and thrombopoietin regulate distinct aspects of human megakaryopoiesis. Blood, 96, 4142-51.

Malaponte G, Polesel J, Candido S, et al (2013). IL-6-174 G > C and MMP-9-1562 $\mathrm{C}>\mathrm{T}$ polymorphisms are associated with increased risk of deep vein thrombosis in cancer patients. Cytokine, 62, 64-9.

Marchioli R, Finazzi G, Landolfi R, et al (2005). Vascular and neoplastic risk in a large cohort of patients with polycythemia vera. J Clin Oncol, 23, 2224-32.

Marquez-Curtis LA, Dobrowsky A, Montaño J, et al (2001). Matrix metalloproteinase and tissue inhibitors of metalloproteinase secretion by haematopoietic and stromal precursors and their production in normal and leukaemic long-term marrow cultures. Br J Haematol, 115, 595-604.

Matrisian LM (1990). Metalloproteinases and their inhibitors in matrix remodeling. Trends Genet, $\mathbf{6}, 121-5$.

Mehtap O, Atesoglu EB, Tarkun P, et al (2012). The association between gene polymorphisms and leukocytosis with thrombotic complications in patients with essential thrombocythemia and polycythemia vera. Turk J Haematol, 29, 162-9.

Ogawa M, Kawamoto M, Yamanaka N (2000). Matrix metalloproteinase and tissue inhibitor of metalloproteinase in human bone marrow tissues-an immunohistochemical study. J Nippon Med Sch, 67, 235-41.

Palei AC, Sandrim VC, Amaral LM, et al (2012). Matrix metalloproteinase-9 polymorphisms affect plasma MMP9 levels and antihypertensive therapy responsiveness in hypertensive disorders of pregnancy. Pharmacogenomics $J, 12,489-98$.

Park KS, Kim SJ, Kim KH, Kim JC (2011). Clinical characteristics of TIMP2, MMP2, and MMP9 gene polymorphisms in colorectal cancer. $J$ Gastroenterol Hepatol, 26, 391-7.

Payandeh M, Zadeh FS, Zare ME, et al (2011). Evalution of common genetic disorders in myeloproliferative neoplasms. IJHOSCR, 5, 16-20.

Pereza N, Ostojic S, Volk M, Kapovic M, Peterlin B (2012). Matrix metalloproteinases 1,2,3 and 9 functional single-nucleotide polymorphisms in idiopathic recurrent spontaneous abortion. Reprod Biomed Online, 24, 567-75. 
Price SJ, Greaves DR, Watkins H (2000). Identification of novel, functional genetic variants in the human matrix metalloproteinase-2 gene:role of Sp1 in allele-specific transcriptional regulation. J Biol Chem, 276, 7549-58.

Rollin J, Regina S, Vourc'h P, et al (2007). Influence of MMP-2 and MMP-9 promoter polymorphisms on gene expression and clinical outcome of non-small cell lung cancer. Lung Cancer, 56, 273-80.

Saeed HM, Alanazi MS, Parine NR, et al (2013). Matrix metalloproteinase-2 (-1306 c $>\mathrm{t})$ promoter polymorphism and risk of colorectal cancer in the Saudi population. Asian Pac J Cancer Prev, 14, 6025-30.

Sanii S, Saffar H, Tabriz HM, et al (2012). Expression of matrix metalloproteinase-2, but not caspase-3, facilitates distinction between benign and malignant thyroid follicular neoplasms. Asian Pac J Cancer Prev, 13, 2175-8.

Scott LM (2013). Lymphoid malignancies: another face to the Janus kinases. Blood Rev, 27, 63-70.

Sfar S, Saad H, Mosbah F, Gabbouj S, Chouchane L (2007). TSP1 and MMP9 genetic variants in sporadic prostate cancer. Cancer Genet Cytogenet, 172, 38-44.

Srivastava P, Kapoor R, Mittal RD (2013). Association of single nucleotide polymorphisms in promoter of matrix metalloproteinase-2, 8 genes with bladder cancer risk in Northern India. Urol Oncol, 31, 247-54.

Soriano G, Heaney M (2013). Polycythemia vera and essential thrombocythemia: new developments in biology with therapeutic implications. Curr Opin Hematol, 20, 169-75.

Sugimoto M, Yoshida S, Kennedy S, et al (2006). Matrix metalloproteinase-1 and -9 promoter polymorphisms and endometrial carcinoma risk in a Japanese population. J Soc Gynecol Investig, 13, 523-9.

Szczudlik P, Borratyńska A (2010). Association between the -1562 C/T MMP-9 polymorphism and cerebrovascular disease in a Polish population. Neurol Neurochir Pol, 44, 350-7.

Tefferi A, Vainchenker W (2011). Myeloproliferative neoplasms: molecular pathophysiology, essential clinical understanding, and treatment strategies. J Clin Oncol, 29, 573-82.

Thorgeirsson UP, Lindsay CK, Cottam DW, Gomez DE (1994). Tumor invasion, proteolysis and angiogenesis. J Neuro Oncol, 18, 89-103.

Travaglino E, Benatti C, Malcovati L, et al (2008). Biological and clinical relevance of matrix metalloproteinases 2 and 9 in acute myeloid leukaemias and myelodysplastic syndromes. Eur J Haematol, 80, 216-26.

Vairaktaris E, Vassiliou S, Nkenke E, et al (2008). A metalloproteinase- 9 polymorphism which affects its expression is associated with increased risk for oral squamous cell carcinoma. Eur J Surg Oncol, 34, 450-5.

Vasku A, Goldbergova M, Izakovicova Holla L, et al (2004). A haplotype constituted of four MMP-2 promoter polymorphisms $(-1575 \mathrm{G} / \mathrm{A},-1306 \mathrm{C} / \mathrm{T},-790 \mathrm{~T} / \mathrm{G}$ and $-735 \mathrm{C} / \mathrm{T}$ ) is associated with coronary triple-vessel disease. Matrix Biol, 22, 585-91.

Wadleigh M, Tefferi A (2010). Classification and diagnosis of myeloproliferative neoplasms according to the 2008 World Health Organization criteria. Int J Hematol, 91, 174-9.

Wagenaar-Miller RA, Gorden L, Matrisian LM (2004). Matrix metalloproteinases in colorectal cancer: is it worth talking about?. Cancer Metastasis Rev, 23, 119-35.

Wang J, Warzecha D, Wilcken D, Wang XL (2001). Polymorphism in the gelatinase $\mathrm{B}$ gene and the severity of coronary arterial stenosis. Clin Sci (Lond), 101, 87-92.

Wang Y, Fang S, Wei L, et al (2005). No association between the $\mathrm{C}-1562 \mathrm{~T}$ polymorphism in the promoter of matrix metalloproteinase-9 gene and non-small cell lung carcinoma.
Lung Cancer, 49, 155-61.

Woo M, Park K, Nam J, Kim JC (2007). Clinical implications of matrix metalloproteinase- $1,-3,-7,-9,-12$, and plasminogen activator inhibitor-1 gene polymorphisms in colorectal cancer. J Gastroenterol Hepatol, 22, 1064-70.

Wu CY, Wu MS, Chen YJ, et al (2007). Clinicopathological significance of MMP-2 and TIMP-2 genotypes in gastric cancer. Eur J Cancer, 43, 799-808.

Xiaoping M, YuAC (2003). Functional polymorphism in the matrix metalloproteinase-2 gene promoter $(1306 \mathrm{C} / \mathrm{T})$ is associated with risk of development but not metastasis of gastric cardia adenocarcinoma. Cancer Res, 63, 3987-90.

Yang TF, Guo L, Wang Q (2014). Meta-analysis of associations between four polymorphisms in the matrix metalloproteinases gene and gastric cancer risk. Asian Pac J Cancer Prev, 15, 1263-7.

Yari K, Rahimi Z, Moradi MT, Rahimi Z (2014). The MMP-2 $-735 \mathrm{C}$ allele is a risk factor for susceptibility to breast cancer. Asian Pac J Cancer Prev, 15, 6199-203.

Yu C, Zhou Y, Miao X, et al (2004). Functional haplotypes in the promoter of matrix metalloproteinase-2 predict risk of the occurrence and metastasis of esophageal cancer. Cancer Res, 64, 7622-8.

Yu XF, Han ZC (2006). Matrix metalloproteinases in bone marrow: roles of gelatinases in physiological hematopoiesis and hematopoietic malignancies. Histol Histopathol, 21, 519-31.

Zhang B, Ye S, Herrmann SM, et al (1999). Functional polymorphism in the regulatory region of gelatinase $\mathrm{B}$ gene in relation to severity of coronary atherosclerosis. Circulation, 99, 1788-94.

Zhang B, Henney A, Eriksson P, et al (1999). Genetic variation at the matrix metalloproteinase-9 locus on chromosome 20q12.2-13.1. Hum Genet, 105, 418-23.

Zhou Y, Yu C, Miao X, et al (2005). Functional haplotypes in the promoter of matrix metalloproteinase- 2 and lung cancer susceptibility. Carcinogenesis, 26, 1117-21. 